\title{
Relationship between atomoxetine plasma concentration, treatment response and tolerability in attention-deficit/ hyperactivity disorder and comorbid oppositional defiant disorder
}

\author{
Philip Hazell · Katja Becker · Eija A. Nikkanen · Paula T. Trzepacz • \\ Yoko Tanaka $\cdot$ Linda Tabas $\cdot$ Deborah N. D'Souza $\cdot$ Jennifer Witcher · \\ Amanda Long · George Ponsler · Ralf W. Dittmann
}

Received: 26 March 2009/ Accepted: 30 August 2009/Published online: 23 September 2009

(C) The Author(s) 2009. This article is published with open access at Springerlink.com

\begin{abstract}
The purpose of this study was to examine whether atomoxetine plasma concentration predicts attention-deficit/hyperactivity disorder (ADHD) or oppositional defiant disorder (ODD) response. This post-hoc analysis assessed the relationship between atomoxetine plasma concentration and ADHD and ODD symptoms in patients (with ADHD and comorbid ODD) aged 6-12 years. Patients were randomly assigned to atomoxetine $1.2 \mathrm{mg} / \mathrm{kg} / \mathrm{day}(n=156)$ or placebo $(n=70)$ for 8 weeks (Study Period II). At the end of 8 weeks, ODD non-remitters (score $>9$ on the SNAP-IV ODD subscale and CGI-I $>2$ ) with atomoxetine plasma concentration $<800 \mathrm{ng} / \mathrm{ml}$ at 2 weeks were re-randomized to either atomoxetine $1.2 \mathrm{mg} / \mathrm{kg} / \mathrm{day}$ or $2.4 \mathrm{mg} / \mathrm{kg} / \mathrm{day}$ for an additional 4 weeks (Study Period III). ODD remitters and non-remitters with plasma atomoxetine $\geq 800 \mathrm{ng} / \mathrm{ml}$ remained on $1.2 \mathrm{mg} / \mathrm{kg} / \mathrm{day}$ atomoxetine for 4 weeks.
\end{abstract}

\section{P. Hazell}

Discipline of Psychological Medicine, Concord Clinical School,

University of Sydney, Sydney, Australia

K. Becker

Department of Child and Adolescent Psychiatry

and Psychotherapy, Central Institute of Mental Health,

Mannheim, Germany

K. Becker

Department of Child and Adolescent Psychiatry

and Psychotherapy, Medical Faculty, Philipps-University

of Marburg, Marburg, Germany

E. A. Nikkanen

Department of Pediatrics, Helsinki University Central Hospital, Peijas Hospital, Vantaa, Finland

E. A. Nikkanen

Folkhälsans Habiliteringsavdelning,

Folkhälsan Raseborg Ltd., Meltola, Finland
Patients who received atomoxetine, completed Study Period II, and entered Study Period III were included in these analyses. All the groups demonstrated improvement on the SNAP-IV ODD and ADHD-combined subscales $(P<.001)$. At the end of Study Periods II and III, ODD and ADHD improvement was significantly greater in the remitter group compared with the non-remitter groups. Symptom improvement was numerically greater in the non-remitter $(2.4 \mathrm{mg} / \mathrm{kg} /$ day compared with the non-remitter $1.2 \mathrm{mg} / \mathrm{kg} /$ day) group. Atomoxetine plasma concentration was not indicative of ODD and ADHD improvement after 12 weeks of treatment. ADHD and ODD symptoms improved in all the groups with longer duration on atomoxetine. Results suggest atomoxetine plasma concentration does not predict ODD and ADHD symptom improvement. However, a higher atomoxetine dose may benefit some patients.

P. T. Trzepacz $(\varangle) \cdot$ Y. Tanaka $\cdot$ L. Tabas ·

D. N. D'Souza · J. Witcher · A. Long · G. Ponsler

Lilly Research Laboratories, Lilly Corporate Center,

Indianapolis, IN 46285, USA

e-mail: ptt@lilly.com

R. W. Dittmann

Eli Lilly Endowed Chair for Pediatric Psychopharmacology,

Central Institute of Mental Health, University of Heidelberg,

Mannheim, Germany

R. W. Dittmann

Department of Child and Adolescent Psychosomatics,

University of Hamburg, Hamburg, Germany 
Keywords Atomoxetine - ADHD .

Plasma concentration · ODD

\section{Introduction}

Attention-Deficit/Hyperactivity Disorder (ADHD) is among the most common neuropsychiatric disorders in childhood and adolescence. The prevalence rates of ADHD in the general population of 6-12-year olds range from 4 to $12 \%$ (Brown et al. 2001). Up to $65 \%$ of children with ADHD may have one or more comorbid conditions (Goldman et al. 1998). Oppositional defiant disorder (ODD) commonly co-occurs with ADHD, and this comorbid group often experiences severe functional impairment (Gadow and Nolan 2002; Drabick et al. 2004). Children with ADHD comorbid with ODD tend to have more severe ADHD symptoms, and family distress, and peer problems when compared with children with ADHD alone (Kuhne et al. 1997).

Atomoxetine, a potent and selective norepinephrine reuptake inhibitor, is used for the treatment of ADHD in children, adolescents and adults. A recent study that examined atomoxetine in pediatric patients aged 6-12 years demonstrated that in patients with ADHD and ODD, treatment with atomoxetine resulted in a significant improvement in ADHD symptoms and global clinical functioning (Bangs et al. 2008).

The bioavailability and clearance of atomoxetine is influenced by the activity of the polymorphically expressed enzyme cytochrome P450 2D6 (CYP2D6) (Sauer et al. 2005). The plasma half-life of atomoxetine ranges from $5.2 \mathrm{~h}$ [extensive metabolizers (EM)] to $21.6 \mathrm{~h}$ (poor metabolizers [PM]), depending on the CYP2D6 phenotype. In CYP2D6 EM, atomoxetine clearance can be reduced by selective CYP2D6 inhibitors (Sauer et al. 2005). When taking atomoxetine doses up to $1.8 \mathrm{mg} / \mathrm{kg}$, CYP2D6 PM are likely to show greater efficacy, an increase in cardiovascular tone, and are somewhat more likely to experience adverse events than EM (Michelson et al. 2007). Since atomoxetine is a relatively new medication, whether particular plasma concentrations might predict level of clinical response is of interest.

In this report, we describe a secondary analysis of a previously published study (Bangs et al. 2008) that assessed the efficacy of atomoxetine in treating symptoms of ODD in children with ADHD and comorbid ODD. The objective of this report is to examine whether atomoxetine plasma concentration predicts symptom response in those patients with ADHD and comorbid ODD, including whether increasing dose is associated with improving response for those who have not fully responded to the usual recommended atomoxetine daily dose.

\section{Materials and methods}

The details for the methods used in this international multicenter clinical study are described in a previous publication (Bangs et al. 2008). Patients were aged 6-12 years and met Diagnostic and Statistical Manual of Mental Disorders, Fourth Edition (DSM-IV) diagnostic criteria for ADHD (hyperactive/impulsive, inattentive, or combined type) and comorbid ODD as determined by clinician assessment, structured clinical interview [Kiddie Schedule for Affective Disorders and Schizophrenia for School Aged ChildrenPresent and Lifetime Version (K-SADS-PL)] (Kaufman et al. 1997), ADHD rating scale, Swanson, Nolan, and Pelham Rating Scale-Revised (SNAP-IV), (Swanson et al. 2001) score above age and gender norms, Clinical Global Impressions-Severity (CGI-S) (Guy 1976; National Institute of Mental Health 1985) score $\geq 4$, and SNAP-IV ODD scores of $\geq 15$.

Patients with a history of bipolar I or II disorder, psychosis, or pervasive developmental disorder were excluded, as were those with a current diagnosis of major depressive disorder, post-traumatic stress disorder, patients with a Children's Depression Rating Scale-Revised (CDRS-R) (Poznanski et al. 1996) total raw score $>40$, serious suicidal risk, history of any seizure disorder (other than febrile seizures), history of alcohol or other drug abuse within the past three months, current cardiovascular disease or other disorders that could be aggravated by increased blood pressure or heart rate, or those who were likely to need psychotropic medications other than atomoxetine during study participation. Additional exclusion criteria details are described in Bangs et al. (2008).

Efficacy measures included the investigator-rated SNAP-IV ODD as well as SNAP-IV ADHD-combined subscales. The SNAP-IV ODD subscale and the SNAP-IV ADHD combined subscale scores were used to measure changes in symptoms of ODD and ADHD. For the analyses reported here, the SNAP-IV ADHD combined subscale scores (total 18 items including both inattention and impulsivity/hyperactivity subscales) and the SNAP-IV ODD subscale scores (total eight items) were evaluated. The CGI-Improvement (CGI-I) scale is a single-item, clinician rating of the total improvement (or worsening) of the patient's symptoms since the beginning of treatment. The CGI-I, as used in this study, was a composite impression of ADHD and ODD symptoms. Improvement was rated on a 7 -point scale $(1=$ very much improved; $7=$ very much worsened). 
After a 3-28-day screening and washout period (Study Period I), 226 patients met entry criteria and were randomized in a 2:1 ratio to receive double-blind treatment with atomoxetine $1.2 \mathrm{mg} / \mathrm{kg} /$ day or placebo for approximately 8 weeks (Study Period II). At Visit 3, after 2 weeks on atomoxetine at a dose of $1.2 \mathrm{mg} / \mathrm{kg} /$ day, patients had blood drawn for atomoxetine plasma concentration. For the blood draw, patients were instructed to hold the morning dose of atomoxetine on the day of Visit 3 and were instructed not to eat anything for at least an hour before their scheduled visit. The patients took their usual dose of study drug in the presence of a member of the investigative staff, and the blood samples were obtained between 60 and $90 \mathrm{~min}$ after the patients had taken atomoxetine. Each patient's atomoxetine plasma concentration results determined their Study Period III (4 weeks) treatment options. In this study, ODD nonremitters were defined by a score of $>9$ on the SNAP-IV ODD subscale and a score of $>2$ on the CGI-I, regardless of their steady-state plasma concentration. At the end of Study Period III, all the patients had blood drawn to determine their peak atomoxetine plasma concentration levels.

The purpose of this study was to assess whether plasma levels at Week 2 or Week 12 were predictive of ADHD and ODD symptom improvement. The measures used were the SNAP-IV ODD subscale scores, the SNAP-IV ADHD combined subscale scores, and the CGI-I at the end of the Study Period II or at the end of the Study Period III.

A blood sample was drawn at the beginning of the study period to determine cytochrome P450 2D6 (CYP2D6) genotype. Adverse events were collected by open-ended discussion at all the visits.

For the purpose of this study, in order to examine if atomoxetine plasma concentration at steady state (Week 2) would predict efficacy outcomes, all the 132 male and female patients who were treated with atomoxetine $1.2 \mathrm{mg} /$ $\mathrm{kg} /$ day and who completed the acute 8-week treatment phase were included in these analyses. Patients were grouped by their dose in Study Period III and ODD remitter status at the end of Study Period II. Subgroups were defined by ODD remitter status at the end of Study Period II. One subgroup comprised 46 patients who were nonremitters and received an increased dose of atomoxetine $2.4 \mathrm{mg} / \mathrm{kg} /$ day during the additional 4 weeks of treatment (Study Period III). The second subgroup comprised the 69 patients who met non-remitter criteria for ODD symptom reduction and remained on atomoxetine $1.2 \mathrm{mg} / \mathrm{kg} / \mathrm{day}$ during the additional 4 weeks of treatment. The third subgroup comprised 17 patients who were ODD remitters and remained on atomoxetine $1.2 \mathrm{mg} / \mathrm{kg} /$ day. Patients who were administered placebo during Study Period II were not included in these analyses.
Bioanalytical method

Human plasma samples obtained during this study were analyzed at SFBC Taylor, located in Princeton, NJ, USA. The samples were analyzed for atomoxetine using a validated LC/APCI/MS/MS method. The lower limit of quantification was $2.50 \mathrm{ng} / \mathrm{ml}$. Samples above the limit of quantification were diluted and reanalyzed to yield results within the calibrated range. The inter-assay accuracy (\% relative error) during validation ranged from -6.05 to $-3.20 \%$, and the inter-assay precision (\% relative standard deviation) during validation ranged from 1.37 to $6.20 \%$. Atomoxetine was stable for up to 15 months when stored at approximately $-70^{\circ} \mathrm{C}$.

\section{Statistical analyses}

The relationships between atomoxetine plasma concentration (both Week 2 and Week 12) and ADHD or ODD symptoms were examined by regression analyses using the atomoxetine plasma concentration as a predictor and the ADHD or ODD symptoms as response variables for Study Periods II and III.

Frequency data were analyzed using the Fisher-Freeman-Halton test for three-way frequencies, and Fisher's exact test for the two-way comparisons.

Unless otherwise noted, continuous data were analyzed using the analysis of variance (ANOVA) model with the term for treatment groups. Baseline was defined as the last available score at Visit 1 or Visit 2.

Analysis of the SNAP-IV subscales was conducted using the analysis of covariance (ANCOVA) model on the last-observation-carried-forward (LOCF) change from baseline to endpoint for Study Periods II and III (up to Week 12). The ANCOVA model included terms of baseline, treatment groups, and investigator. Tests were evaluated based on a two-sided significance level of 0.05 . Multiplicity was not adjusted since this analysis was exploratory. Throughout the manuscript, the term "significant" denotes "statistical significance" unless otherwise specified.

\section{Results}

Baseline demographics and other variables

The demographic characteristics for the three subgroups (Table 1) showed that the majority of patients were male, Caucasian, had ADHD combined subtype, did not have a family history of ADHD, had previous stimulant use, and had an extensive metabolizer (EM) CYP2D6 genotype. The overall mean age range was $9.26-10.40$ years. The 
Table 1 Patient baseline characteristics

\begin{tabular}{|c|c|c|c|c|}
\hline Event & $\begin{array}{l}\text { Non-remitter atomoxetine } \\
2.4 \mathrm{mg} / \mathrm{kg} / \text { day }(N=46)\end{array}$ & $\begin{array}{l}\text { Non-remitter atomoxetine } \\
1.2 \mathrm{mg} / \mathrm{kg} / \text { day }(N=69)\end{array}$ & $\begin{array}{l}\text { Remitter atomoxetine } \\
1.2 \mathrm{mg} / \mathrm{kg} / \text { day }(N=17)\end{array}$ & $\begin{array}{l}\text { Total } \\
(N=132)\end{array}$ \\
\hline Age, yr mean $(\mathrm{SD})^{*^{\mathrm{a}}}$ & $9.3(1.9)$ & $9.7(1.7)$ & $10.4(1.8)$ & $\mathrm{n} / \mathrm{a}$ \\
\hline \multicolumn{5}{|l|}{ Gender, $n(\%)^{*^{\mathrm{a}}}$} \\
\hline Female & $0(0.0)$ & $7(10.1)$ & $2(11.8)$ & $9(6.8)$ \\
\hline Male*b & $46(100.0)$ & $62(89.9)$ & $15(88.2)$ & $123(93.2)$ \\
\hline \multicolumn{5}{|l|}{ DSM-IV ADHD subtype, $n(\%)$} \\
\hline Hyperactive & $1(2.2)$ & $6(8.7)$ & $0(0.0)$ & $7(5.3)$ \\
\hline Inattentive & $5(10.9)$ & $8(11.6)$ & $0(0.0)$ & $13(9.9)$ \\
\hline Combined & $40(87.0)$ & $55(79.7)$ & $17(100)$ & $112(84.9)$ \\
\hline Weight, $\mathrm{kg}$ mean $(\mathrm{SD}) * * * \mathrm{a}, * * * \mathrm{c}$ & $32.0(8.1)$ & $33.7(8.7)$ & $41.8(8.0)$ & $34.1(8.9)$ \\
\hline Height, cm mean $(\mathrm{SD}) * * \mathrm{a}, * \mathrm{c}$ & $135.0(11.9)$ & $137.6(11.0)$ & $144.2(9.9)$ & $137.6(11.5)$ \\
\hline \multicolumn{5}{|l|}{ Previous stimulant use, $n(\%)$} \\
\hline No & $15(32.6)$ & $23(33.3)$ & $4(23.5)$ & $42(31.8)$ \\
\hline Yes & $31(67.4)$ & $46(66.7)$ & $13(76.5)$ & $90(68.2)$ \\
\hline \multicolumn{5}{|l|}{ Metabolizer type, $n(\%)^{\mathrm{d}}$} \\
\hline Extensive metabolizer & $46(100.0)$ & $66(97.1)$ & $15(88.2)$ & $127(97.0)$ \\
\hline Poor metabolizer & $0(0.0)$ & $2(2.9)$ & $2(11.8)$ & $4(3.1)$ \\
\hline \multicolumn{5}{|l|}{ Origin, $n(\%)$} \\
\hline Caucasian & $41(89.1)$ & $67(97.1)$ & $17(100.0)$ & $125(94.7)$ \\
\hline Hispanic & $2(4.4)$ & $0(0.0)$ & $0(0.0)$ & $2(1.5)$ \\
\hline Other & $3(6.5)$ & $2(2.9)$ & $0(0.0)$ & $5(3.8)$ \\
\hline \multicolumn{5}{|l|}{ No family history ADHD, $n(\%)$} \\
\hline Mother & $42(91.3)$ & $66(95.7)$ & $17(100.0)$ & $125(94.7)$ \\
\hline Father & $39(84.8)$ & $55(79.7)$ & $16(94.1)$ & $110(83.3)$ \\
\hline Grandparent & $39(84.8)$ & $57(82.6)$ & $17(100.0)$ & $113(85.6)$ \\
\hline Siblings & $35(76.1)$ & $51(73.9)$ & $16(94.1)$ & $102(77.3)$ \\
\hline
\end{tabular}

n/a not applicable, $S D$ standard deviation, DSM-IV diagnostic and statistical manual of mental disorders, fourth edition, $A D H D$ attention-deficit/ hyperactivity disorder

$* P<.05, * * P<.01, * * * P<.001$

a Non-remitter atomoxetine $2.4 \mathrm{mg} / \mathrm{kg} /$ day versus remitter atomoxetine $1.2 \mathrm{mg} / \mathrm{kg} /$ day

b Non-Remitter Atomoxetine $2.4 \mathrm{mg} / \mathrm{kg} /$ day versus non-remitter atomoxetine $1.2 \mathrm{mg} / \mathrm{kg} / \mathrm{day}$

c Non-remitter atomoxetine $1.2 \mathrm{mg} / \mathrm{kg} /$ day versus remitter atomoxetine $1.2 \mathrm{mg} / \mathrm{kg} /$ day

${ }^{\mathrm{d}} n=68$ for non-remitter atomoxetine $1.2 \mathrm{mg} / \mathrm{kg} /$ day group

mean age of the non-remitter $2.4 \mathrm{mg} / \mathrm{kg} / \mathrm{day}$ group was significantly lower than the remitter $1.2 \mathrm{mg} / \mathrm{kg} / \mathrm{day}$ group $(P=.035)$. The non-remitter $2.4 \mathrm{mg} / \mathrm{kg} / \mathrm{day}$ group had significantly more male patients $(100 \%)$ than the nonremitter $1.2 \mathrm{mg} / \mathrm{kg} /$ day group [89.86\% $(P=.041)]$.

At study entry, patients in the Study Period III ODD remitter $1.2 \mathrm{mg} / \mathrm{kg} /$ day group were significantly taller and weighed more than patients in the non-remitter $2.4 \mathrm{mg} / \mathrm{kg} /$ day and non-remitter $1.2 \mathrm{mg} / \mathrm{kg} / \mathrm{day}$ groups; while height and weight were not significantly different between the non-remitter groups. There were 16 patients in the nonremitter $1.2 \mathrm{mg} / \mathrm{kg} /$ day group with plasma concentrations $>800 \mathrm{ng} / \mathrm{ml}$ at Week 2 .
There were no significant differences between the three subgroups as regards reasons for discontinuation from the study (Table 2).

The baseline mean SNAP-IV ADHD combined and ODD subscale scores were similar with no significant differences among groups (Table 3). These scores indicate moderate disease severity.

Symptom ratings and atomoxetine plasma concentrations

In Study Period II, after 2 weeks of treatment with atomoxetine $1.2 \mathrm{mg} / \mathrm{kg} / \mathrm{day}$, mean atomoxetine plasma 
Table 2 Primary reason for study discontinuation

\begin{tabular}{|c|c|c|c|c|}
\hline Primary reason for discontinuation $^{\mathrm{a}}$ & $\begin{array}{l}\text { Non-remitter atomoxetine } \\
2.4 \mathrm{mg} / \mathrm{kg} / \mathrm{day} \\
{[N=46, n(\%)]}\end{array}$ & $\begin{array}{l}\text { Non-remitter atomoxetine } \\
1.2 \mathrm{mg} / \mathrm{kg} / \text { day } \\
{[N=69, n(\%)]}\end{array}$ & $\begin{array}{l}\text { Remitter atomoxetine } \\
1.2 \mathrm{mg} / \mathrm{kg} / \text { day } \\
{[N=17, n(\%)]}\end{array}$ & $\begin{array}{l}\text { Total } \\
{[N=132,} \\
n(\%)]\end{array}$ \\
\hline Adverse event & $2(4.3)$ & $0(0.0)$ & $0(0.0)$ & $2(1.5)$ \\
\hline $\begin{array}{l}\text { Lack of efficacy (patient and physician } \\
\text { perception) }\end{array}$ & $3(6.5)$ & $4(5.8)$ & $0(0.0)$ & $7(5.3)$ \\
\hline Lack of efficacy (patient perception) & $0(0.0)$ & $2(2.9)$ & $0(0.0)$ & $2(1.5)$ \\
\hline $\begin{array}{l}\text { Personal conflict or other patient } \\
\text { decision }\end{array}$ & $1(2.2)$ & $0(0.0)$ & $0(0.0)$ & $1(0.8)$ \\
\hline Unable to contact patients/caregiver & $0(0.0)$ & $1(1.4)$ & $0(0.0)$ & $1(0.8)$ \\
\hline
\end{tabular}

${ }^{a}$ There were no significant differences across or between any groups

Table 3 SNAP-IV ADHD combined subscale and ODD subscale baseline scores (Visit 1 and Visit 2; pre-atomoxetine treatment), mean change from baseline scores, and CGI-I scores by Study Period III ODD response group status

\begin{tabular}{|c|c|c|c|c|c|}
\hline Scale and ODD response group & $\begin{array}{l}N=132 \\
(n)\end{array}$ & $\begin{array}{l}\text { Baseline }^{\mathrm{a}} \\
\text { mean }(\mathrm{SD})\end{array}$ & $\begin{array}{l}\text { Week } 2 \text { (steady state) change } \\
\text { from baseline mean (SD) }\end{array}$ & $\begin{array}{l}\text { Week } 8^{\mathrm{b}} \text { change from } \\
\text { baseline mean }(\mathrm{SD})\end{array}$ & $\begin{array}{l}\text { Week } 12^{\mathrm{c}} \text { change from } \\
\text { baseline mean (SD) }\end{array}$ \\
\hline \multicolumn{6}{|c|}{ SNAP-IV ADHD combined subscale } \\
\hline Non-remitter (2.4) & 46 & $45.2(5.4)$ & $-8.7(10.0)$ & $-10.3(8.8)$ & $-14.3(11.0)$ \\
\hline Non-remitter (1.2) & 69 & $44.2(7.4)$ & $-5.6(9.6)$ & $-6.4(9.4)$ & $-10.9(10.3)$ \\
\hline Remitter (1.2) & 17 & $44.3(4.8)$ & $-16.5(8.4)$ & $-28.7(9.3)$ & $-26.4(14.2)$ \\
\hline \multicolumn{6}{|l|}{ SNAP-IV ODD subscale } \\
\hline Non-remitter (2.4) & 46 & $18.9(2.7)$ & $-4.1(5.0)$ & $-3.2(4.1)$ & $-5.5(5.5)$ \\
\hline Non-remitter (1.2) & 69 & $19.0(2.2)$ & $-3.1(5.0)$ & $-2.1(4.4)$ & $-4.4(5.1)$ \\
\hline Remitter (1.2) & 17 & $18.1(1.8)$ & $-6.8(5.0)$ & $-12.9(2.3)$ & $-9.5(6.2)$ \\
\hline \multicolumn{6}{|l|}{$\mathrm{CGI}^{\mathrm{d}}{ }^{\mathrm{d}}$} \\
\hline Non-remitter (2.4) & 46 & d & $3.4(1.0)$ & $3.4(1.2)$ & $2.9(1.0)$ \\
\hline Non-remitter (1.2) & 69 & d & $3.8(1.3)$ & $3.8(1.3)$ & $3.2(1.3)$ \\
\hline Remitter (1.2) & 17 & d & $2.7(1.1)$ & $1.5(0.5)$ & $2.0(1.3)$ \\
\hline
\end{tabular}

SNAP-IV Swanson, Nolan, and Pelham rating scale-revised, $A D H D$ attention-deficit/hyperactivity disorder, $O D D$ oppositional defiant disorder, $C G I-I$ clinical global impression-improvement, $S D$ standard deviation

a There were no significant differences across or between any groups at baseline

b End of Study Period II, all the patients on atomoxetine $1.2 \mathrm{mg} / \mathrm{kg} / \mathrm{day}$; rerandomized at Week 8 to $1.2 \mathrm{mg} / \mathrm{kg} / \mathrm{day}$ or $2.4 \mathrm{mg} / \mathrm{kg} / \mathrm{day}$ atomoxetine

${ }^{c}$ End of Study Period III, patient subgroups (ODD response group status) on same dose of $1.2 \mathrm{mg} / \mathrm{kg} / \mathrm{day}$ or higher dose of $2.4 \mathrm{mg} / \mathrm{kg} / \mathrm{day}$ for 4 weeks

${ }^{\mathrm{d}}$ No baseline score for this scale

concentrations (steady state) were significantly lower for patients who were designated in Study Period III as the ODD non-remitter $2.4 \mathrm{mg} / \mathrm{kg} /$ day group $(n=46)$ as compared with either the non-remitter $1.2 \mathrm{mg} / \mathrm{kg} /$ day group ( $n=69, P<.001$ ), or the remitter $1.2 \mathrm{mg} / \mathrm{kg} /$ day group ( $n=17, P=.002)$. No significant differences were seen between the non-remitter $1.2 \mathrm{mg} / \mathrm{kg} /$ day and the remitter $1.2 \mathrm{mg} / \mathrm{kg} /$ day groups $(n=17, P=.062])$ at Week 2 (Table 4). After 12 weeks of atomoxetine treatment (end of Study Period III), Week 2 plasma concentrations did not significantly predict ADHD and ODD outcomes for any group using regression analysis. Furthermore, Week 12 plasma levels did not predict end of study ADHD or ODD outcomes for any group using regression analysis (data not shown).

Table 4 displays atomoxetine mean plasma concentrations for all the three groups at Weeks 2 and 12. Atomoxetine plasma concentration at Week 12 for the non-remitter $2.4 \mathrm{mg} / \mathrm{kg} /$ day group was significantly greater compared to the non-remitter $1.2 \mathrm{mg} / \mathrm{kg} /$ day group $(P<.001)$. However, at Week 12, the non-remitter $2.4 \mathrm{mg} / \mathrm{kg} /$ day group did not demonstrate significantly greater improvement compared 
Table 4 Atomoxetine plasma concentrations (ng/ml) by Study Period III ODD response group status

\begin{tabular}{|c|c|c|c|c|c|c|c|c|c|c|}
\hline \multirow{2}{*}{$\begin{array}{l}\text { Study Period III ODD } \\
\text { response group status }\end{array}$} & \multicolumn{5}{|c|}{ Week 2 (steady state) } & \multicolumn{5}{|c|}{ Week 12} \\
\hline & $N$ & Mean (SD) & Median & Minimum & Maximum & $N$ & Mean (SD) & Median & Minimum & Maximum \\
\hline Non-remitter $(2.4 \mathrm{mg} / \mathrm{kg} /$ day $)$ & 41 & $348.0(191.4)$ & 351.4 & 8.5 & 745.5 & 42 & $849.1(532.3)$ & 741.9 & 23.9 & 2403.1 \\
\hline Non-remitter $(1.2 \mathrm{mg} / \mathrm{kg} / \mathrm{day})$ & 60 & $581.2 * * *(366.7)$ & 488.8 & 28.3 & 1825.0 & 63 & $564.0 * * *(316.9)$ & 527.7 & 18.4 & 1331.4 \\
\hline $\operatorname{Remitter}(1.2 \mathrm{mg} / \mathrm{kg} / \mathrm{day})$ & 17 & $873.6 * *(989.2)$ & 535.8 & 4.7 & 3716.9 & 15 & $635.5(411.4)$ & 477.0 & 128.0 & 1212.0 \\
\hline
\end{tabular}

Note: Because this study included all the patients who entered Study Period III, patients in the non-remitter $1.2 \mathrm{mg} / \mathrm{kg} / \mathrm{day}$ atomoxetine group included patients with steady-state atomoxetine plasma concentration values $>800 \mathrm{ng} / \mathrm{ml}$

$O D D$ oppositional defiant disorder, $S D$ standard deviation

*** $P<.001$ non-remitter $2.4 \mathrm{mg} / \mathrm{kg} /$ day versus non-remitter $1.2 \mathrm{mg} / \mathrm{kg} / \mathrm{day}$

** $P<.01$ non-remitter $2.4 \mathrm{mg} / \mathrm{kg} /$ day versus remitter $1.2 \mathrm{mg} / \mathrm{kg} /$ day

with the non-remitter $1.2 \mathrm{mg} / \mathrm{kg} /$ day group on the SNAP-IV ADHD subscale score $(P=.050)$, the SNAP-IV ODD subscale score, or the CGI-I score (Table 3). Atomoxetine plasma concentration at Week 12 in the non-remitter $2.4 \mathrm{mg} /$ $\mathrm{kg} /$ day group was not significantly different from the remitter $1.2 \mathrm{mg} / \mathrm{kg} /$ day group. Similarly, the atomoxetine plasma concentration of the non-remitter $1.2 \mathrm{mg} / \mathrm{kg} / \mathrm{day}$ group at Week 12 was not significantly different from the remitter $1.2 \mathrm{mg} / \mathrm{kg} /$ day group.

Table 3 demonstrates the mean change from baseline to Weeks 2, 8, and 12 for the SNAP-IV ADHD combined subscale scores and the SNAP-IV ODD subscale scores. The CGI-I scores at Weeks 2, 8, and 12 are also shown. The remitter $1.2 \mathrm{mg} / \mathrm{kg} /$ day group demonstrated significantly greater ADHD symptom improvement from baseline to Week 12 on the SNAP-IV ADHD combined subscale score $(P=.024)$, and the CGI-I score $(P=.008)$ compared with the non-remitter $2.4 \mathrm{mg} / \mathrm{kg} / \mathrm{day}$ group, and on the SNAP-IV ADHD combined subscale score $(P<.001)$, the SNAP-IV ODD subscale score $(P=.013)$, and the CGI-I score $(P=.002)$ with the non-remitter $1.2 \mathrm{mg} / \mathrm{kg} /$ day group (Table 3). Similar results were seen with significantly greater improvement in the remitter $1.2 \mathrm{mg} / \mathrm{kg} / \mathrm{day}$ group from baseline to Week 8 on the SNAP-IV ADHD combined subscale score $(P<.001)$, the SNAP-IV ODD subscale score $(P<.001)$, and the CGI-I score $(P=.014)$ compared with the non-remitter $2.4 \mathrm{mg} / \mathrm{kg} / \mathrm{day}$ group, and on the SNAP-IV ADHD combined subscale score $(P<.001)$, the SNAP-IV ODD subscale score $(P<.001)$ and the CGI-I score $(P<.001)$ with the non-remitter $1.2 \mathrm{mg} / \mathrm{kg} /$ day group.

On the SNAP-IV ADHD-combined subscale scores, the remitter $1.2 \mathrm{mg} / \mathrm{kg} /$ day group experienced significant improvement compared with either non-remitter group, from baseline to each week displayed in Fig. 1. Similar results were demonstrated at every visit on the SNAP-IV ODD subscale with the exception of Week 2 (no significant difference compared with non-remitter $1.2 \mathrm{mg} / \mathrm{kg} / \mathrm{day}$ group) and 12 (no significant difference compared with non-remitter $2.4 \mathrm{mg} / \mathrm{kg} /$ day group) (Fig. 2).

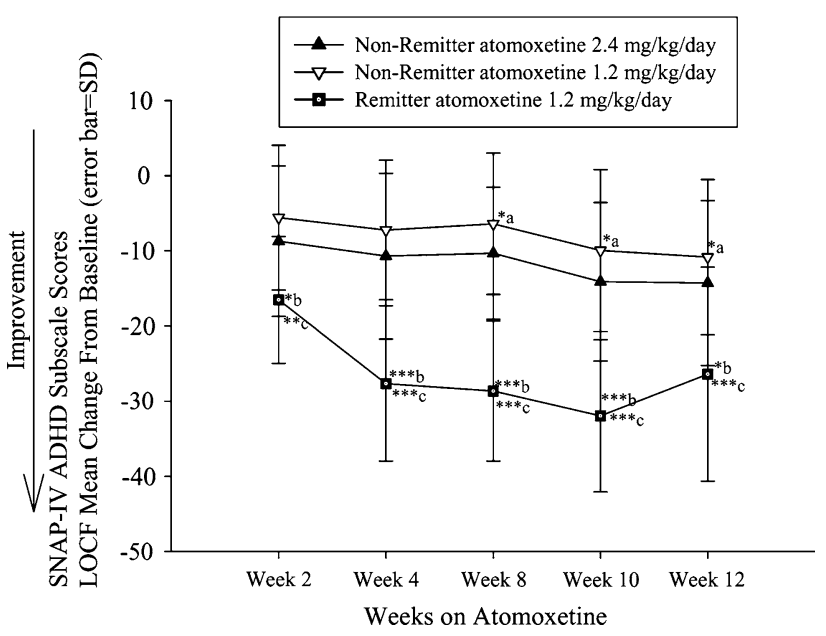

Fig. 1 Visitwise mean change from baseline to week on atomoxetine for SNAP-IV ADHD combined subscale scores (last-observationcarried-forward) by Study Period III ODD response groups. ${ }^{a} P$-value comparison non-remitter atomoxetine $2.4 \mathrm{mg} / \mathrm{kg} /$ day versus Non-remitter atomoxetine $1.2 \mathrm{mg} / \mathrm{kg} /$ day, ${ }^{\mathrm{b}} P$-value comparison non-remitter atomoxetine $2.4 \mathrm{mg} / \mathrm{kg} /$ day versus remitter atomoxetine $1.2 \mathrm{mg} / \mathrm{kg} /$ day, ${ }^{\mathrm{c} P} P$-value comparison non-remitter atomoxetine $1.2 \mathrm{mg} / \mathrm{kg} / \mathrm{day}$ versus Remitter atomoxetine $1.2 \mathrm{mg} / \mathrm{kg} /$ day; $* P<.05$; $* * P<.01$; $* * * P<.001$

In both non-remitter groups, there was continuing ODD and ADHD symptom improvement from Weeks 8 to 12 with longer atomoxetine treatment irrespective of whether the dose was increased. The non-remitter $2.4 \mathrm{mg} / \mathrm{kg} / \mathrm{day}$ group showed a significant improvement at Week 8 $(P=.014)$ and Week $10(P=.033)$ on the SNAP-IV ADHD combined subscale compared with the non-remitter $1.2 \mathrm{mg} / \mathrm{kg} /$ day group. No significant differences between the non-remitter groups were seen on the SNAP-IV ODD subscale scores from baseline to Weeks 2, 4, 6, 8, and 12 (all $P \geq .05$ ).

As seen in Fig. 3, at every visit from Weeks 2 to 12 there was a significantly greater improvement on the CGI-I ADHD/ODD score in the remitter $1.2 \mathrm{mg} / \mathrm{kg} /$ day group compared with the non-remitter $2.4 \mathrm{mg} / \mathrm{kg} / \mathrm{day}$ group or the non-remitter $1.2 \mathrm{mg} / \mathrm{kg} /$ day group. From Weeks 2 to 


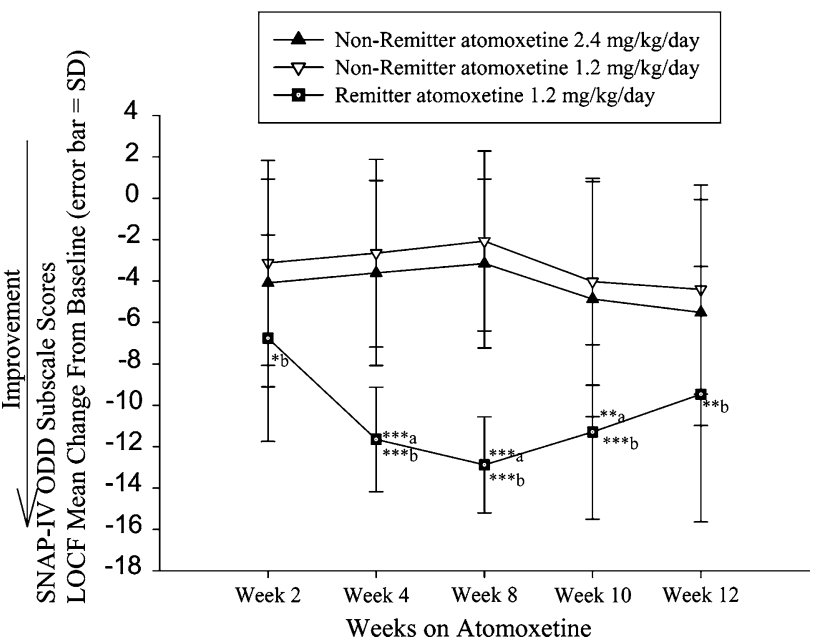

Fig. 2 Visitwise mean change from baseline to week on atomoxetine for SNAP-IV ODD combined subscale (mean and SD) scores (lastobservation-carried-forward) by Study Period III ODD response groups. ${ }^{\mathrm{a}} P$-value comparison non-remitter atomoxetine $2.4 \mathrm{mg} / \mathrm{kg} /$ day versus remitter atomoxetine $1.2 \mathrm{mg} / \mathrm{kg} / \mathrm{day},{ }^{\mathrm{b}} P$-value comparison non-remitter atomoxetine $1.2 \mathrm{mg} / \mathrm{kg} / \mathrm{day}$ versus remitter atomoxetine $1.2 \mathrm{mg} / \mathrm{kg} /$ day; $* P<.05 ; * * P<.01 ; * * * P<.001$

12, there were no significant differences in the CGI-I ADHD/ODD score between the non-remitter groups.

\section{Safety}

There were no deaths reported in any subgroup. There were no discontinuations due to adverse events (AEs) in the remitter $1.2 \mathrm{mg} / \mathrm{kg} / \mathrm{day}$ group or the non-remitter $1.2 \mathrm{mg} / \mathrm{kg} / \mathrm{day}$ group. Two out of 46 patients $(4.3 \%)$ in the non-remitter

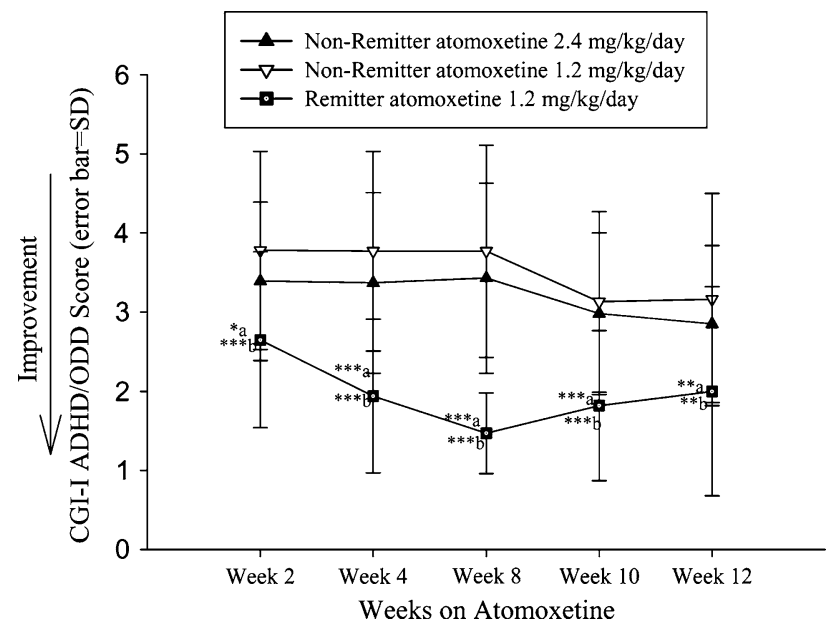

Fig. 3 Clinical global impression-improvement ADHD/ODD visitwise scores by Study Period III ODD remitter groups. ${ }^{\mathrm{a}} P$-value comparison non-remitter atomoxetine $2.4 \mathrm{mg} / \mathrm{kg} / \mathrm{day}$ versus remitter atomoxetine $1.2 \mathrm{mg} / \mathrm{kg} / \mathrm{day},{ }^{\mathrm{b}} P$-value comparison non-remitter atomoxetine $1.2 \mathrm{mg} / \mathrm{kg} / \mathrm{day}$ versus remitter atomoxetine $1.2 \mathrm{mg} / \mathrm{kg} / \mathrm{day}$; $* P<.05 ; * * P<.01 ; * * * P<.001$
$2.4 \mathrm{mg} / \mathrm{kg} / \mathrm{day}$ group discontinued from the whole study due to an $\mathrm{AE}$ [aspartate aminotransferase increased $(n=1,2.2 \%)$, tic $(n=1,2.2 \%)$ ]. No patients in the non-remitter $1.2 \mathrm{mg} / \mathrm{kg} /$ day group or the remitter $1.2 \mathrm{mg} / \mathrm{kg} /$ day group discontinued during Weeks 8-12.

There were no significant differences between treatment groups in the total number of patients with $\geq 1$ treatmentemergent adverse events (TEAEs) (Table 5). There was a greater incidence $(P=.005)$ of nasopharyngitis in the nonremitter $2.4 \mathrm{mg} / \mathrm{kg} /$ day group $(n=12,26.09 \%)$ compared with the non-remitter $1.2 \mathrm{mg} / \mathrm{kg} /$ day group $(n=4,5.80 \%)$. Abdominal pain occurred with greater incidence $(P=.048)$ in the non-remitter $1.2 \mathrm{mg} / \mathrm{kg} /$ day group $(n=10,14.49 \%)$ compared with the non-remitter $2.4 \mathrm{mg} / \mathrm{kg} /$ day group $(n=1,2.17 \%)$. There was a greater incidence $(P=.028)$ of vomiting in the remitter $1.2 \mathrm{mg} / \mathrm{kg} /$ day group $(n=6$, $35.29 \%$ ) compared with the non-remitter $1.2 \mathrm{mg} / \mathrm{kg} / \mathrm{day}$ group $(n=8,11.59 \%)$.

\section{Discussion}

The findings of this study suggest that although some patients may benefit from higher atomoxetine plasma concentrations, exposure alone may not be indicative of therapeutic outcome for ADHD or ODD symptoms in children with ADHD and comorbid ODD. Using the same study population, Bangs et al. (2008) previously reported that ADHD and comorbid ODD patients who did not achieve adequate ODD symptom reduction after 8 weeks on atomoxetine $1.2 \mathrm{mg} / \mathrm{kg} / \mathrm{day}$ and who also had lower steady-state atomoxetine plasma concentrations $(<800$ $\mathrm{ng} / \mathrm{ml}$ ) at Week 2 did not benefit from 4 more weeks on atomoxetine even at a doubled dose. Although this retrospective analysis of non-remitters included all the patients regardless of their Week 2 atomoxetine plasma concentration, analyses found that Week 2 steady-state atomoxetine plasma concentration was not indicative of either ODD or ADHD symptom improvement. These results were consistent when comparing Week 2 atomoxetine plasma concentration at the end of 8 weeks of treatment when all the patients were on atomoxetine $1.2 \mathrm{mg} / \mathrm{kg} / \mathrm{day}$ and when comparing Week 12 atomoxetine plasma concentration after the non-remitter atomoxetine $2.4 \mathrm{mg} / \mathrm{kg} / \mathrm{day}$ group had been on the higher atomoxetine dose for 4 weeks. These data suggest that other factors are involved in determining therapeutic response to atomoxetine. In addition, plasma concentrations at Week 12 also did not predict therapeutic response in any of the three ODD response groups.

Perhaps, the most compelling evidence is demonstrated by the group comparisons for ODD non-remitters. The non-remitter $2.4 \mathrm{mg} / \mathrm{kg} / \mathrm{day}$ group was not significantly 
Table 5 Summary of treatment-emergent adverse events with $\geq 5 \%$ incidence by remitter and treatment subgroup

\begin{tabular}{lllll}
\hline Adverse event & Non-remitter atomoxetine & Non-remitter atomoxetine & Remitter atomoxetine & Total \\
& $2.4 \mathrm{mg} / \mathrm{kg} /$ day $[N=46, n(\%)]$ & $1.2 \mathrm{mg} / \mathrm{kg} /$ day $[N=69, n(\%)]$ & $1.2 \mathrm{mg} / \mathrm{kg} / \mathrm{day}[N=17, n(\%)]$ \\
{$[N=132, n(\%)]$}
\end{tabular}

TEAE treatment-emergent adverse event

$* P<.05, * * P<.01$

${ }^{\text {a }}$ Non-remitter atomoxetine $2.4 \mathrm{mg} / \mathrm{kg} /$ day versus non-remitter atomoxetine $1.2 \mathrm{mg} / \mathrm{kg} / \mathrm{day}$

${ }^{\text {b } O v e r a l l ~} P$-value and non-remitter $2.4 \mathrm{mg} / \mathrm{kg} / \mathrm{day}$ versus non-remitter $1.2 \mathrm{mg} / \mathrm{kg} / \mathrm{day}$

${ }^{c}$ Non-remitter Atomoxetine $1.2 \mathrm{mg} / \mathrm{kg} / \mathrm{day}$ versus remitter atomoxetine $1.2 \mathrm{mg} / \mathrm{kg} / \mathrm{day}$

different from the non-remitter $1.2 \mathrm{mg} / \mathrm{kg} / \mathrm{dose}$ group at Week 2 on the SNAP-IV ADHD subscale, the SNAP-IV ODD subscale, or the CGI-I where Week 2 atomoxetine plasma concentrations were significantly higher in the nonremitter $1.2 \mathrm{mg} / \mathrm{kg} /$ day group. Further, as demonstrated in the visitwise figures for clinical outcomes for ADHD and ODD, at endpoint and throughout the study, the two ODD non-remitter groups had similar clinical symptom severities that did not differ much from Week 2, even though the $2.4 \mathrm{mg} / \mathrm{kg} /$ day group had a significantly higher atomoxetine plasma concentration at Week 12 compared to the nonremitter $1.2 \mathrm{mg} / \mathrm{kg} /$ day group. Both these findings suggest that not responding adequately on ODD symptoms at Week 8 could not have been predicted by plasma concentration after 2 weeks on treatment.

At Week 2, the remitter $1.2 \mathrm{mg} / \mathrm{kg} /$ day group showed significantly greater atomoxetine plasma concentrations than the non-remitter $2.4 \mathrm{mg} / \mathrm{kg} /$ day group but not significantly different from the non-remitter $1.2 \mathrm{mg} / \mathrm{kg} /$ day group. At Week 12, the atomoxetine plasma concentrations in the remitter $1.2 \mathrm{mg} / \mathrm{kg} /$ day group were not significantly different from either of the ODD non-remitter groups. Yet, the remitter $1.2 \mathrm{mg} / \mathrm{kg} / \mathrm{day}$ group demonstrated greater improvement compared to either non-remitter group on the SNAP-IV ADHD subscale, SNAP-IV ODD subscale, and CGI-I at every visit (Figs. 1, 2, 3). Interestingly, the remitter $1.2 \mathrm{mg} / \mathrm{kg} /$ day group demonstrated a worsening of ADHD and ODD symptoms at Weeks 10 and 12, whereas both non-remitter groups demonstrated continued or sustained improvement on the SNAP-IV ODD subscale, the SNAP-IV ADHD subscale and the CGI-I (Figs. 1, 2, 3). In fact, both non-remitter groups demonstrated continuing ODD and ADHD symptom improvement from Weeks 8 to 12 with longer atomoxetine treatment irrespective of whether the dose was increased. It is difficult to interpret what this means, however, given that longitudinal studies can show fluctuations in response levels the longer the study progresses.

Although there have been reported cases suggesting greater efficacy in treatment of ADHD symptoms with increased dose or serum levels of atomoxetine, (Michelson et al. 2007; Paulzen et al. 2008) few studies have examined whether atomoxetine plasma concentrations would predict outcome. A study of methylphenidate blood levels and therapeutic response to ADHD symptom improvement (Teicher et al. 2006) reported a waxing and waning of response directly related to higher and lower plasma levels of methylphenidate, respectively.

However, recent studies have shown no significant improvement in ADHD symptoms using higher doses of atomoxetine (Kratochvil et al. 2007). Results of two atomoxetine dose comparison studies presented together showed a significant reduction in ADHD-RS score in both studies with no significant differences between high dose (mean atomoxetine dose; $2.49 \mathrm{mg} / \mathrm{kg} /$ day and $2.1 \mathrm{mg} / \mathrm{kg} /$ day) and low dose groups (mean atomoxetine dose; 
$1.58 \mathrm{mg} / \mathrm{kg} / \mathrm{day}$, and $1.1 \mathrm{mg} / \mathrm{kg} / \mathrm{day})$. Corroborating findings were reported in a study comparing atomoxetine treatment in PM versus EM patients with ADHD (Trzepacz et al. 2008) when physicians were blinded to the CYP2D6 status of patients and the atomoxetine dose was adjusted based on ADHD symptom improvement and tolerability, dose distribution largely overlapped between groups despite differences in plasma concentration (10-fold higher steady-state average plasma concentration in PM versus EM). The higher atomoxetine plasma concentrations in PM patients may not be predictive of treatment response. It may be that achieving some minimum cerebrospinal fluid concentration for effects on the central nervous system norepinephrine transporter, along with genetic and pharmacodynamic factors, are more important than plasma pharmacokinetics.

Indeed, complexities in treatment outcome may be related to heterogeneous neuropsychiatric impairment reported in patients with ADHD. A comparison of atomoxetine-treated ADHD patients who were stimulanttreatment naive with those who were previously stimulantresponsive found sustained symptom improvement in both treatment groups, although the stimulant-naive group demonstrated a slightly greater response rate (Newcorn et al. 2007). Recent evidence has shown that transporter genotype may play a role in variation of treatment outcome: genotype of the dopamine transporter (DAT1) played a role in ADHD treatment outcome with methylphenidate (Bellgrove et al. 2005). Further, positron emission tomography (PET) studies have shown evidence in non-human primates of a relationship between atomoxetine dose and norepinephrine (NE) transporter occupancy in the brain (Seneca et al. 2006). Further PET studies may elucidate whether a relationship exists between effective $\mathrm{NE}$ transporter occupancy levels and atomoxetine plasma concentration.

The findings of this study are limited by several factors. The primary study from which these analyses were derived was designed to evaluate the clinical effect of increased atomoxetine doses only in patients who were ODD non-remitters with steady-state plasma concentrations $<800 \mathrm{ng} / \mathrm{ml}$ after 2 weeks of atomoxetine treatment regardless of their ADHD response (Bangs et al. 2008). The objective of this report was post hoc, and the sample size in some subgroups was small and unbalanced between groups. In addition, because of the different regrouping of patients for this study, patients in the atomoxetine non-remitter $2.4 \mathrm{mg} / \mathrm{kg} / \mathrm{day}$ group all had steady-state plasma concentrations $<800 \mathrm{ng} / \mathrm{ml}$ during Weeks $8-12$. The non-remitter and remitter groups treated with atomoxetine $1.2 \mathrm{mg} / \mathrm{kg} /$ day during Weeks 8-12 included patients with plasma concentrations, both less than and $>800 \mathrm{ng} / \mathrm{ml}$.
In conclusion, for patients with ADHD and comorbid ODD who have an initial inadequate response, plasma concentration may not be an indicator of outcome and additional improvements. Clinical implications for treatment efficacy suggest that routine monitoring of atomoxetine plasma concentration is probably not necessary unless there is another reason such as poor adherence being suspected.

Acknowledgment This study was supported by Eli Lilly and Company, Indianapolis, Indiana, USA.

Conflict of interest statement Paula Trzepacz, Linda Tabas, Deborah D'Souza, Jennifer Witcher, Amanda Long, George Ponsler, and Yoko Tanaka are employees and stockholders of Eli Lilly and Company (Indianapolis, Indiana, USA). Ralf Dittmann is a stockholder and former employee of Eli Lilly and Company (Lilly Deutschland, Bad Homburg, Germany). Philip Hazell participates in Australian and international advisory boards, is on the speakers' bureau, and receives research grants from Eli Lilly and Company. Eija Nikkanen has received research grants for Protocol Addendum B4Z-MC-LYBX (Protocol Addendum of A Randomized, DoubleBlind Comparison of Atomoxetine Hydrochloride and Placebo in Child and Adolescent Outpatients with Attention-Deficit/Hyperactivity Disorder and Comorbid Oppositional Defiant Disorder) from: (1) Eli Lilly and Company Research Foundation, (2) The Maud Kuistila Memorial Foundation, and (3) The Märta Donner Foundation. Kajta Becker served in a consultancy role either personally or for an employee from Eli Lilly and Company, was on the speakers' bureaus of Eli Lilly and Company and Astra Zeneca (Wedel, Germany), participates in the Advisory Board of Eli Lilly and Company, and received conference attendance support from Shire Deutschland $\mathrm{GmbH}$ (Cologne, Germany).

Open Access This article is distributed under the terms of the Creative Commons Attribution Noncommercial License which permits any noncommercial use, distribution, and reproduction in any medium, provided the original author(s) and source are credited.

\section{References}

Bangs ME, Hazell P, Danckaerts M et al (2008) Atomoxetine for the treatment of attention-deficit/hyperactivity disorder and oppositional defiant disorder. Pediatrics 121(2):e314-e320

Bellgrove MA, Hawi Z, Kirley A et al (2005) Association between dopamine transporter (DAT1) genotype, left-sided inattention, and an enhanced response to methylphenidate in attentiondeficit/hyperactivity disorder. Neuropsychopharmacology 30: 2290-2297

Brown RT, Freeman WS, Perrin JM et al (2001) Prevalence and assessment of attention-deficit/hyperactivity disorder in primary care settings. Pediatrics 107(3):E43

Drabick DAG, Gadow KD, Carlson GA et al (2004) ODD and ADHD symptoms in Ukrainian children: external validators and comorbidity. J Am Acad Child Adolesc Psychiatr 43(6):735-743

Gadow KD, Nolan EE (2002) Differences between preschool children with ODD, ADHD, and ODD + ADHD symptoms. J Child Psychol Psychiatr 43(2):191-201

Goldman LS, Genel M, Bezman RJ et al (1998) Diagnosis and treatment of attention-deficit/hyperactivity disorder in children 
and adolescents. Council on scientific affairs, American Medical Association. JAMA 279(14):1100-1107

Guy W (1976) ECDEU Assessment manual for psychopharmacology, revised. Publication ADM 76-338. United States Department of Health, Education, and Welfare, Bethesda, Md

Kaufman J, Birmaher B, Brent D et al (1997) Schedule for affective disorders and schizophrenia for school-age children-present and lifetime version (K-SADS-PL): initial reliability and validity data. J Am Acad Child Adolesc Psychiatr 36(7):980-988

Kratochvil CJ, Michelson D, Newcorn JH et al (2007) High-dose atomoxetine treatment of ADHD in youths with limited response to standard doses. J Am Acad Child Adolesc Psychiatr 46(9): $1128-1375$

Kuhne M, Schachar R, Tannock R (1997) Impact of comorbid oppositional or conduct problems on attention-deficit/hyperactivity disorder. J Am Acad Child Adolesc Psychiatr 36(12): 1715-1725

Michelson D, Read HA, Ruff DD et al (2007) CYP2D6 and clinical response to atomoxetine in children and adolescents with ADHD. J Am Acad Child Adolesc Psychiatr 46(2):242-251

National Institute of Mental Health (1985) Clinical global impressions. Psychopharmacol Bull 21:839-843

Newcorn H, Zhang S, Rogers AK et al (2007) Atomoxetine treatment response in ADHD patients naïve to previous pharmacotherapy. Presented at the 13th international congress of the european society for child and adolescent psychiatry (ESCAP), August 25-29, 2007, Florence, Italy

Paulzen M, Clement HW, Gründer G (2008) Enhancement of atomoxetine serum levels by co-administration of paroxetine. Int J Neuropsychopharmacol 11(2):289-291. Epub 2007 Sep 28

Poznanski EO, Mokros HB (1996) Children's depression rating scale, revised (CDRS-R) manual. Western Psychological Services, Los Angeles

Sauer JM, Ring BJ, Witcher JW (2005) Clinical pharmacokinetics of atomoxetine. Clin Pharmacokinet 44(6):571-590

Seneca N, Gulyás B, Varrone A et al (2006) Atomoxetine occupies the norepinephrine transporter in a dose-dependent fashion: a PET study in nonhuman primate brain using $(\mathrm{S}, \mathrm{S})-[18 \mathrm{~F}] \mathrm{FMeN}-$ ER-D2. Psychopharmacology (Berl) 188(1):119-127

Swanson JM, Kraemer HC, Hinshaw SP et al (2001) Clinical relevance of the primary findings of the MTA: success rates based on severity of ADHD and ODD symptoms at the end of treatment. J Am Acad Child Adolesc Psychiatr 40:168-179

Teicher MH, Polcari A, Foley M et al (2006) Methylphenidate blood levels and therapeutic response in children with attention-deficit/ hyperactivity disorder I. Effects of different dosing regimens. J Child Adolesc Psychopharmacol 16(4):416-431

Trzepacz PT, Williams DW, Feldman PD et al (2008) CYP2D6 metabolizer status and atomoxetine dosing in children and adolescents with ADHD. Eur Neuropsychopharmacol 18(2):79-86 